\title{
Using forensic science to teach method development in the undergraduate analytical laboratory
}

\author{
Kimberley A. Frederick
}

Published online: 10 May 2013

(C) Springer-Verlag Berlin Heidelberg 2013

The "analytical method" or the process of conducting an analysis to obtain statistically meaningful information is one of the first topics covered in many analytical chemistry textbooks [1-3]. Understanding how to take an analysis protocol from the literature, develop it, validate it, and use it to analyze an unknown sample is arguably one of the most important skills taught to students in the laboratory portion of an analytical chemistry course. Although very important, this topic is not one that has inherent interest for most students. This article details our efforts to increase student learning by embedding the method development process in a criminal case.

Forensic science has often been successfully used to increase student engagement in the chemistry classroom. Examples include exercises and laboratories in courses for nonscience majors $[4,5]$, general chemistry $[6,7]$, and organic chemistry [8]. Forensic science laboratories have often been used as the context for teaching more standard laboratory techniques in both quantitative analysis and instrumental analysis courses [9-11]. Thompson and Edmiston [12] reported using a multiweek, forensic science project in the analytical chemistry teaching laboratory. The project detailed in this article builds on their work with an intentional focus on the method development process in a multiweek experience that holds students accountable for their data quality with a mock trial and a nontechnical police report as summative exercises.

\section{Overview of the project}

The forensic science project begins about 1 month before the official start date, when students are presented with the

\footnotetext{
K. A. Frederick $(\bowtie)$

Department of Chemistry, Skidmore College, 815 N Broadway, Saratoga Springs, NY 12866, USA

e-mail: kfreder1@skidmore.edu
}

initial information about the crime. This has come in several forms, including mock newspaper articles and suspect interviews. Students are placed into teams of four or five and are given requests for analysis which include pieces of evidence from the crime scene, comparison pieces of evidence from various suspects (if appropriate), and the identity of the analyte to be detected. Ideas for possible evidence were garnered from articles in the Journal of Chemical Education, the Journal of Forensic Sciences, and the Analytical Sciences Digital Library (http://home.asdlib.org/). A summary of different pieces of evidence provided through the years is shown in Table 1. The team size is determined by the laboratory section size so that each student has his or her own piece of evidence that he or she is responsible for analyzing. Laboratory sections typically house 16 students, so the laboratory is divided into four teams of four (two prosecution teams and two defense teams). The laboratory experiments run for 3-4 weeks. The exercise concludes with a mock trial and a written report.

Students are assessed on the basis of four different aspects of this project:

1. Planning before the laboratory

2. Performance in the laboratory

3. Testimony at the mock trial

4. Quality of their written report

\section{Pre-experimental planning}

While students continue to do more standard exercises in the laboratory, they are responsible for searching the literature to determine two or three possible analytical methods. They are limited by the instruments available in the department. Additionally, the pieces of evidence were chosen so that the most likely instrument method would be different for each piece of evidence. Approximately 3 weeks before the start 
Table 1 Examples of evidence used in the forensics project

\begin{tabular}{|c|c|c|c|}
\hline Type of evidence & Comparison samples & Method for preparing sample & Instrumental method used \\
\hline Swab with gunshot residue & $\begin{array}{l}\text { Gunshot residue from guns found } \\
\text { at the residence of other suspects }\end{array}$ & $\begin{array}{l}\text { Cotton swabs doped with metal } \\
\text { salts and dried }\end{array}$ & $\begin{array}{l}\text { Atomic absorption spectroscopy with } \\
\text { graphite furnace atomization and X- } \\
\text { ray fluorescence spectroscopy }\end{array}$ \\
\hline Note found at the scene & $\begin{array}{l}\text { Pens found in the possession of } \\
\text { suspects }\end{array}$ & $\begin{array}{l}\text { Single note is written and sampled } \\
\text { by multiple students }\end{array}$ & $\begin{array}{l}\text { High-performance liquid } \\
\text { chromatography and capillary } \\
\text { electrophoresis }\end{array}$ \\
\hline Fiber found on the victim & $\begin{array}{l}\text { Fibers from the clothing of the } \\
\text { suspects }\end{array}$ & $\begin{array}{l}\text { Fibers collected from around } \\
\text { campus }\end{array}$ & $\begin{array}{l}\text { Fourier transform infrared } \\
\text { spectroscopy and high-performance } \\
\text { liquid chromatography }\end{array}$ \\
\hline Blood to be tested for alcohol & Blood with no alcohol & Animal plasma doped with ethanol & $\begin{array}{l}\text { Gas chromatography with headspace } \\
\text { analysis }\end{array}$ \\
\hline $\begin{array}{l}\text { Brain tissue (simulated) with } \\
\text { metal residue }\end{array}$ & $\begin{array}{l}\text { Similarly sized weapons from } \\
\text { suspects' residences }\end{array}$ & $\begin{array}{l}\text { Hamburger mixed with small } \\
\text { metal particles }\end{array}$ & $\begin{array}{l}\text { Atomic absorption spectroscopy with } \\
\text { graphite furnace atomization }\end{array}$ \\
\hline Urine from victim for poisoning & $\begin{array}{l}\text { Open bottle of pills found at the } \\
\text { suspect's home }\end{array}$ & $\begin{array}{l}\text { Simulated urine (water and food } \\
\text { coloring) doped with drugs }\end{array}$ & $\begin{array}{l}\text { High-performance liquid } \\
\text { chromatography and fluorescence } \\
\text { spectroscopy }\end{array}$ \\
\hline $\begin{array}{l}\text { Explosives residue found on } \\
\text { crime scene evidence }\end{array}$ & $\begin{array}{l}\text { Explosives found at the suspects' } \\
\text { home }\end{array}$ & $\begin{array}{l}\text { Explosive standard solutions } \\
\text { dropped onto evidence and dried }\end{array}$ & $\begin{array}{l}\text { High-performance liquid } \\
\text { chromatography }\end{array}$ \\
\hline
\end{tabular}

of the project, students meet individually with the instructor to choose the method they will pursue. Rarely, students will have chosen methods which will not work and will need to go back to the literature. Two weeks before the start of the project, students must submit a list of chemicals, supplies, and equipment needed so that anything not available can be purchased in time for the start of the project. These items often include filters and derivatizing agents for sample pretreatment and rarely cost more than a few hundred dollars in total between all the students, which is often reasonable for 4 weeks' worth of laboratory work. Although there is some time in between weeks to purchase new chemicals and supplies, it is usually easiest to have most of the materials in advance.

Although the method development process has been covered in detail in class and in the laboratory, students are often still confused about how to develop an appropriate standard or how to use standard reference materials. We also discuss how different standards can be used to differentiate the instrumental uncertainty from the method uncertainty. Having to work through the steps independently helps clarify the importance of the analytical method and its value in ensuring reliable and reproducible results.

\section{Experimental process}

Once the experimental work starts, much of the focus shifts to data acquisition, evaluation, and troubleshooting. Students quickly learn that it does not work to just take data and then wait until the laboratory period is over to analyze the quality. They take ownership of the data analysis and understanding of the significance of the data because they realize that they will need to report their results to their peers. During this part of the project, the laboratory instructor serves merely as an advisor who helps guide students to their own solutions rather than just fixing things. Being available to help students work through data analysis and experiment planning was essential for their continued progress through the exercise. Much of this occurred during regular office hours.

Evaluation for this part of course is based on three key elements. Do students come prepared for the laboratory each week with a plan? Students should come with a procedural plan for what they will do in the laboratory each week based on the results of the previous week's work. Are students able to troubleshoot problems with their experimental methods on the basis of knowledge from previous laboratory experiences? Although students may need help here, their ability to propose logical next steps is an important summative experience. Can students produce valid analytical results? On the basis of careful attention to detail and a good experimental plan, students should be able to go through the steps involved in method development to produce a valid result. Of course, unanticipated factors, such as instrumentation malfunction, could play a mitigating factor in this part of the assessment.

\section{Final stage: mock trial and police report}

During the last week of the laboratory experience, the prosecution team must decide who will be prosecuted during the mock trial and inform the defense. The mock trial is set up 
in a configuration very similar to that used at Oberlin College [12]. The faculty member serves as the judge, and a jury is recruited from staff in the chemistry department as well as the student laboratory workers. Each team begins with an opening statement which should set up the line of defense. The expert witnesses for the prosecution testify, followed by the defense experts. Finally, each team gives a closing statement. After the closing statements, the jury deliberates and decides on a verdict.

During their testimony, the students testify about the analysis and significance of their data. Students can bring in any appropriate visual aids to help with their presentation. Because the jury members may include individuals who have not had a course in analytical chemistry, students are asked to prepare their testimony for a nontechnical audience. The opposing side is allowed to cross-examine each witness. In order to avoid overzealous cross-examination, all questions are submitted to the judge to be asked. This opportunity to ask questions is a very important motivator for the students. It helps them to understand the work they have done and makes them highly invested in having good-quality, defensible data. Students are evaluated on their individual testimony alone. Extra credit of 1-2\% is awarded to the winning team to encourage good opening and closing statements.

Each student is also asked to individually write a report which would theoretically be provided to the police detectives or lawyers, a nontechnical audience. One of the aspects lacking in a traditional undergraduate curriculum involves communicating science to a nontechnical audience. This exercise challenges the students to write without the typical chemical jargon and in a framework that provides sufficient information to be informative but does not overwhelm the reader with details. We have informal discussions about this balance during the entire laboratory process so students begin to see their work through nontechnical eyes. Students' reports are evaluated for both clarity and effectiveness at addressing the appropriate audience.

\section{Summary of results and observations}

On the basis of experience, I offer the following observations and suggestions for those considering implementing a similar activity in their course. Involving a senior student who is not currently enrolled in the course for crime development and planning has been very helpful. After several iterations of this activity, my own creativity and ability to come up with new crime scenarios and evidence became depleted. It was also very helpful to have tried out the experiments in advance to determine where particular difficulties might arise. The senior student also served in this capacity. Each student will ideally arrive at the same analytical result for each piece of evidence. It is important, therefore, to develop evidence that gives an inconclusive criminal result. For example, results such as a blood alcohol level corresponding to a state between intoxicated and comatose keeps things interesting. If all of the results point to a very clear criminal conclusion, then the trial will be an anticlimactic defeat for one of the teams. Finally, it was also important to provide clear instructions about the trial so that students understand the group function of the opening and closing statements and how their evidence is related to this. Each student can become so fixated on his or her individual testimony that he or she neglects to put in sufficient effort synthesizing all the pieces of evidence into an overall narrative about the crime. When this aspect receives sufficient attention, then the trial becomes a fun exercise. In summary, this project runs smoothly with sufficient planning and troubleshooting.

Overall, both students and faculty have found this project to result in larger learning gains than those experienced in the traditional week-to-week laboratories. There are several aspects of this project which seem to foster greater investment by students in the quality of their planning and results: wanting to contribute to the overall success of their team, having to defend their results during cross-examination, and a competitive spirit which arises between the defense and prosecution teams. Students report on course evaluations that they enjoy this experience far more than the traditional laboratory format.

Acknowledgments The author acknowledges financial support from the Camille and Henry Dreyfus Foundation and the National Science Foundation (DUE 0941951) as well as invaluable help from Antonet Desouza-Gooding, Kyle Soucy, and Estela Trebicka in the development and coordination of this work.

\section{References}

1. Harris DC (2010) Quantitative chemical analysis, 8th edn. Freeman, New York

2. Robinson JW, Skelly Frame EM, Frame GM (2005) Undergraduate instrumental analysis, 6th edn. Dekker, New York

3. Skoog DA, West DM, Holler FJ, Crouch SR (2012) Fundamentals of analytical chemistry, 9th edn. Brooks Cole Cengage, Stamford

4. Szalay PS, Zook-Gerdau LA, Schurter EJ (2011) A multitechnique forensic experiment for a nonscience-major chemistry course. J Chem Educ 88:1419-1421

5. Labianca DA (2007) Science and the nonscience major: addressing the fear factor in the chemical arena using forensic science. J Coll Sci Teach 28-33

6. Maurer MK, Bukowkski MR, Menachery MD, Zatorsky AR (2010) Inquiry-based arson investigation for general chemistry using GC-MS. J Chem Ed 311-313

7. Yousefzadeh MJ, Martin EM, Rogers AL (2007) A guided-inquiry approach to the general chemistry laboratory. Chem Educ 396-398 
8. Konaklieva M (2004) Accidental drowning or foul play? a case study in organic chemistry. J Coll Sci Teach 10-13

9. Bender S, Lillard SJ (2003) Was the suspect in contact with the victim? an instrumental methods experiment for the analysis of single fibers using FT-IR microscopy. J Chem Educ 437-440

10. Rose RE, Fitzgerald N (2011) Incorporating a forensic science problem-solving activity into an analytical chemistry laboratory course. Chem Educ 319-322

11. Tarr MA (2001) Solving a mock arsenic-poisoning case using atomic spectroscopy. J Chem Educ 61-62

12. Thompson RQ, Edmiston PL (2001) Ohio crime solvers: students combine chemistry and cooperative labs to solve "murders". Anal Chem 679A-684A

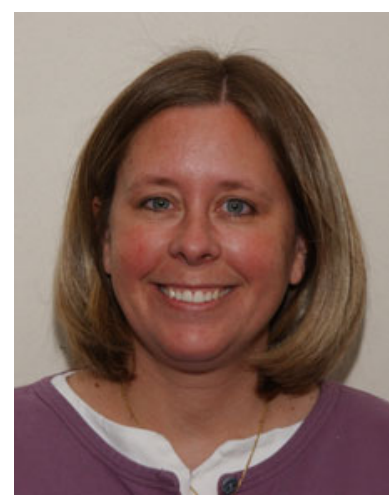

Kimberley A. Frederick is Professor of Analytical Chemistry and Chair of the Department of Chemistry at Skidmore College. Her research involves developing new smart materials for capillary electrophoresis and microfluidics, fundamental studies of electroosmotic flow, and adaptation of biomedical tests to microfluidic chips. She also conducts research in chemical education, specifically the use of discovery chemistry in general and analytical chemistry. 